\title{
Diversity of Rotifers of Rajapalayam Taluk, Virudhunagar District, Tamil Nadu, India
}

\author{
Suresh Kumar, R*. and M. Senraj* \\ $P G$ and Research Department of Zoology, Ayya Nadar Janaki Ammal College, Sivakasi \\ ${ }^{\#}$ Assistant Professor of Zoology, RDM College, Sivagangai \\ *Present address: Taxidermist, Southern Regional Station, Zoological Survey of India, Chennai
}

\begin{abstract}
A study on the diversity of rotifers was carried out in seasonal and perennial ponds of Rajapalayam taluk, Virudhunagar district, for a period of 8 months from July 2007 to February 2008. During the study, 45 species of rotifers belonging to 10 families were documented. Among the 45 species, 11 are new records for the state and the recording of Brachionus donneri after its first description from the state is noteworthy.
\end{abstract}

Key words: Brachionus donneri, Diversity, Rotifers, Tamil Nadu, Virudhunagar district

\section{INTRODUCTION}

Rotifers, the wheel animalcules, could be readily recognized by their small size $(0.4 \mathrm{~mm}$ to $3.0 \mathrm{~mm})$ and the wheel like rotating structure present at the anterior end. They are omnivorous filter feeders and their abundance depends on the amount of the predation from invertebrates and small fish [1]. They are regarded as one of the valuable indicator organisms in biological monitoring studies [2].

This group fascinated the scientists worldwide by their distribution, structure and their use in aquaculture [3,4,5,6,7,8]. Though there are studies on Indian rotifera, Sharma [9] opines that they are scanty. In Tamil Nadu, the studies are very much limited compared to other states of India. Edmondson and Hutchinson [10] initiated the studies on rotifers in Tamil Nadu. After that, many workers [11, 12,13,14,15,16,17,18,19,20] contributed to the fauna of this state. Recently, Raghunathan and Suresh Kumar [2] inventoried 158 species of rotifers belonging to 53 genera under 22 families and 3 orders.

In Virudhunagar district, this group escapes the attention of researches for a long time and very few works on plankton ecology comprised part of zooplankton taxonomy and ecology [21, 22, 23]. There is no exclusive report on the occurrence of this group from this part of Tamil Nadu. Hence, it is proposed to make a survey of water bodies in and around Rajapalayam taluk, and to analyse the nature based on the presence or absence of indicator organisms.

\section{MATERIAL AND MethodS}

The zooplankton samples were collected from various water bodies such as, seasonal ponds, pools, quarries, perennial ponds, etc. in Rajapalayam taluk, using $25 \mathrm{~cm}$ dia. plankton net made up of bolten silk $(40 \mu$ mesh size). Plankton were preserved in 5\% neutral formalin. From this the rotifers were separated and temporary mounts were made using glycerin. The rotifers were identified based on standard key characters $[8,9,24]$.

\section{RESULT}

In the present study, 45 species of rotifers have been recorded. The systematic list of the species recorded from the samples is given below:

$\begin{array}{ll}\text { Phylum } & : \text { Rotifera } \\ \text { Subclass } & : \text { Eurotatoria Bartos } \\ \text { Super order } & : \text { Monogononta Wesenberg-Lund } \\ \text { Order } & : \text { Ploimida Delage } \\ \text { Family } & : \text { Brachionidae Wesenberg-Lund }\end{array}$

1. Brachionus angularis Gosse

2. Brachionus bidentatus Anderson

3. Brachionus calyciflorus Pallas

4. Brachionus caudatus Barrois \&Daday

5. Brachionus diversicornis (Daday)

6. Brachionus donneri Brehm

7. Brachionus falcatus Zacharias

8. Brachionus forficula Wierzejski 
9. Brachionus patulus (O.F.Muller)

10. Brachionus patulus patulus (O.F. Muller)

11. Brachionus plicatilis O.F.Muller

12. Brachionus pterodiondes Rousselet - New record

13. Brachionus quadridentatus Hermann

14. Brachionus quadridentatus brevispinus (Ehrenberg)

15. Brachionus urceolaris O.F.Muller

16. Brachionus sp. 1

17. Brachionus sp. 2

18. Keratella quadrata (O.F.Muller)

19. Keratella tropica (Apstein)

20. Platyas quadricornis Ehrenberg

Family : Epiphanidae

21. Epiphanes clavulata (Ehrenberg)

22. Epiphanes macroura (Barrais and Daday)

Family : Euchlanidae Bartos

23. Dipleuchlanis propatula (Gosse)

24. Euchlanis brahmae (Dhanapathi) - New record

Family : Mytilinidae

25. Mytilina ventralis Ehrenberg

Family : Colurellidae Bartos

26. Lepadella(Lepadella) ovalis

27. Lepadella(Lepadella) quadricarinata (Sternroes) - New record

Family : Lecanidae Bartos

28. Lecane (Monostyla) bulla (Gosse)

29. Lecane(Monostyla) lunaris lunaris (Ehrenberg)

30. Lecane(Monostyla) quadridentata (Ehrenberg)

31. Lecane(Lecane) curvicornis curvicornis (Murray)

32. Lecane(Lecane) hamata (Stokes) - New record

33. Lecane(Lecane) hastata (Murray) - New record

34. Lecane(Lecane) leontina (Turner)

35. Lecane(Lecane) papuana (Murray)

36. Lecane(Lecane) verecunda - New record

37. Lecane tesselata - New record

Family : Notommatidae Remane

38. Cepholodella catellina (Muller) - New record

39. Scaridium longicaudatum (Muller) - New record

Family : Asplanchnidae

40. Asplanchna brightwelli Gosse

$\begin{array}{ll}\text { Order } & : \text { Gnesiotrocha De Beauchamp } \\ \text { Suborder } & : \text { Flosculariacea Remane } \\ \text { Family } & : \text { Testudinellidae Bartos }\end{array}$

41. Testudinella mucronata - New record

42. Testudinella patina (Hermann)

Family

: Filinidae Bartos

43. Filinia longiseta (Ehrenberg)

44. Filinia terminalis (Plate)

$\begin{array}{ll}\text { Super order } & \text { : Digononta } \\ \text { Subclass } & \text { : Bdelloidea } \\ \text { Order } & \text { : Bdelloida } \\ \text { Family } & \text { : Habrotrachidae }\end{array}$

45. Rotaria neptunea (Ehrenberg) - New record

\section{DISCUSSION}

In the present study 45 species of fresh water rotifers belonging to 15 genera and 11 families were recorded which comprises of $28.5 \%$ of the Tamil Nadu rotifer fauna. Among the 16 species of Brachionus reported from Tamil Nadu [2], 13 are represented in the present investigation, which comprises $81 \%$. The genus Brachionus is entirely absent in arctic region [25], whereas it is significantly increased in equatorial and tropical regions. This concept correlates well with the present study. It is also interesting to note that Brachionus 
donneri, a cosmopolitan species, is reported for the first time after its first description [2] from Tamil Nadu. Brachionus and Lecane are the dominant genera of this study which are represented by 17 and 10 species respectively. The species richness of these two genera may be attributed to the general tropical character. The order wise representation of rotifer fauna of the present study is given in Fig. 1 and the Ploimidan composition is represented in the Fig. 2.

The study reveals that the monogonont taxa of Rajapalayam taluk are dominant (44 species) when compared to digonont taxa (1 species). This pattern corresponds well with the species diversity of Tamil Nadu rotifer fauna (150 species of Monogonont taxa and 8 species of Digonont taxa) [2]. The limited diversity of digonont taxa may be attributed to inadequate and proper analysis of collections. Among the 45 species recorded 11 are recorded for the first time from this state. Hence, the total number of species recorded from this state is increased to 169 species [2]. With the inclusion of the findings in the present study, the species composition of the monogonont taxa is increased to 160 species and the digonont taxa to 10 .

Species recorded in the present study are categorized into many types, such as, warm stenothermal, viz., Brachionus falcatus, B. forficula, Keratella tropica; Eurythermal, viz., Brachionus angularis, B. angularis, B. calyciflorus, B. rubens, Lecane hamata and Testudinella patina. The temperate species are B. diversicornis and B. quadridentatus. Brachionus angularis, B. calyciflorus, B. falcatus, Keratella tropica Asplanchna brightwelli and Filinia longiseta are representing the alkaline species. Most of the species represented in the genus Brachionus are bioindicators.

Some of the cosmopolitan species like, Brachionus angularis, B. calyciflorus, B. caudatus, and $B$. quadridentatus were recorded in the present study. The species, B. angularis, B. calyciflorus documented in the study are indicators of eutrophication and a pollution indicator B. plicatilis, is also noted.
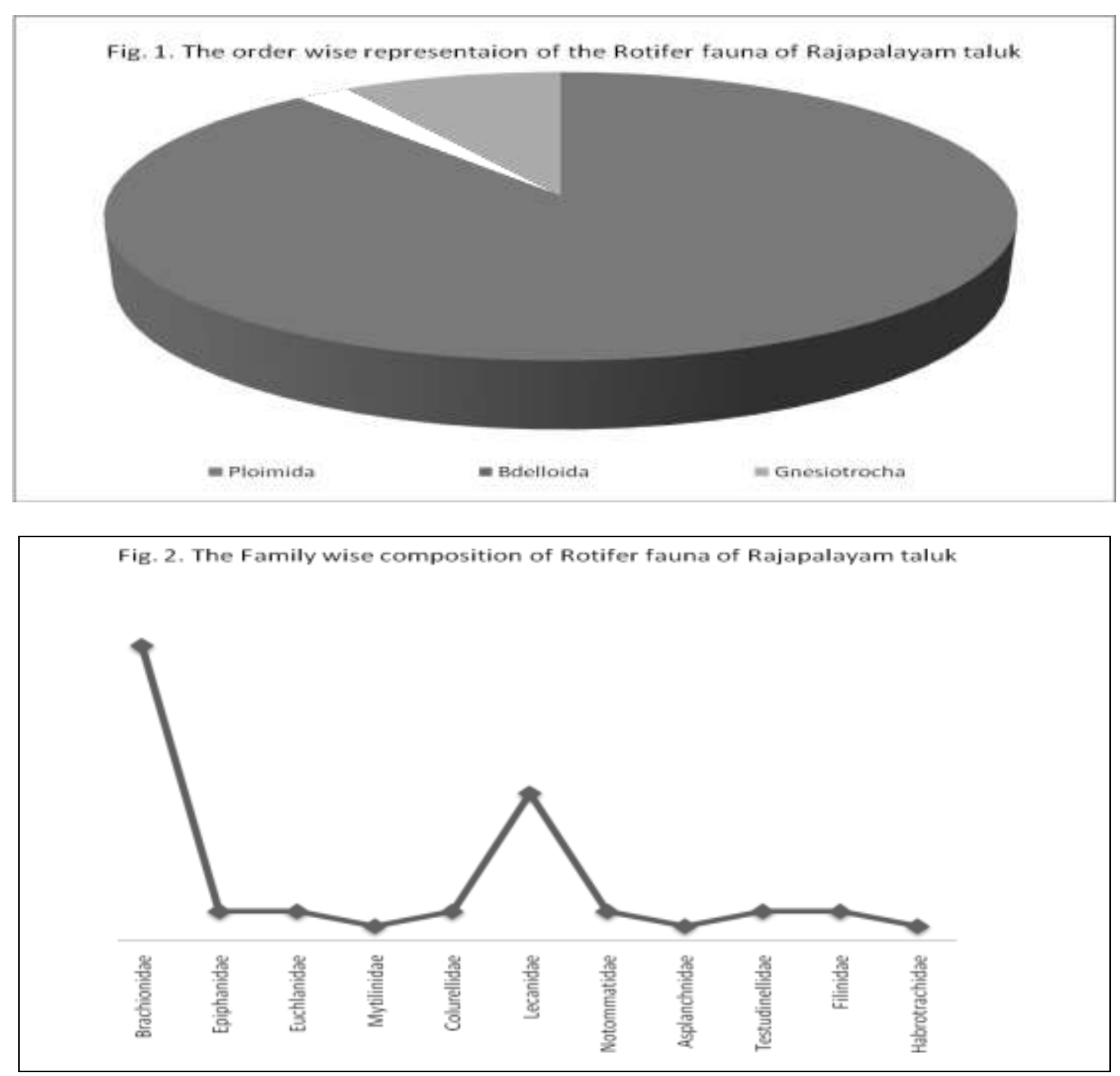


\section{CONCLUSION}

The studies on rotifer fauna of Virudhunagar district is much limited, though the studies from various taluks of this district indicates that species composition is rich and can be compared with other districts. The studies on Srivilliputtur taluk yielded 9 species [26] and from Sivakasi taluk 18 species were reported [23,27]. Our knowledge on the fauna of rotifers of Rajapalayam taluk is still not complete. The correct identification and proper collection from various water bodies may enhance the rotifer fauna of this taluk as well as the fauna of Virudhunagar district.

\section{ACKNOWLEDGEMENTS}

The authors are thankful to the management and to the principal for providing the necessary facilities.

\section{REFERENCES}

[1] K. V. Ramesh, Environmental Microbiology (MJP publishers, Chennai, 2004)

[2] M. B. Raghunathan and R. Suresh Kumar, Diversity of Rotifers of Tamil Nadu. Rec. Zool Surv. India., 106 (2), 2006, 67-78.

[3] H.S. Jennings, Rotatoria of the United States with special reference to great lakes. Bull. US Fish. Comm., Washington, 19, 1900, 67 $-104$.

[4] H. Sudzuki, Rotifer from South Australia. Proc. Jap. S. Zool., 3, 1967, 17 - 19.

[5] R. Chengalnath and C.H. Fernando, Rotifers from Sri Lanka (Ceylon), I. Genus Lecane with descriptions of two new species. Bull. Fish Res. Stn. Sri Lanka., 24, 1973, 13-27.

[6] H. J. Dumont and M. De Ridder, Rotifers from Turkey, Hydrobiologia, 147, 1987, 65-73.

[7] B. K. Sharma, Rotifera (Animal Resources of India-state of art. ZSI, 1991).

[8] M.V.S.S.S. Dhanapathi, Taxonomic notes on the rotifers from India (from 1889 - 2000) (IAAB, Publication No. 10, Hyderabad,2000).

[9] B. K. Sharma, Rotifera (Faunal Diversity in India. Eds. J.R.B. Altred, A.K. Das and A.K Sanyal. Envis centre, Zoological Survey of India, 1998)

[10] W. T. Edmondson and G.E. Hutchinson, Report of Rotatoria. Article IX. Yale North Indian Expedition. Mem. Conn. Acad. Arts. Sci., 10, 1934, 153-186.

[11] J. Hauer, Neue Rotatorian aus Indien, III Zool. Anz., 120, 1937,17 - 19.

[12] E. H. Ahlstrom, A revision of the Rotatorian genus Keratella with descriptions of three new species and five new varieties. Bull. Am. Mus. Nat. Hist., 80, 1943, $411-457$.

[13] V. Brehm, Ein neure Brachionus aus Indian (Brachionmus donneri), Zool. Anz., 146, 1951, 54-55.

[14] S. M. K. Pasha, On a collection of fresh water zooplankton from Madras. J. Zool. Soc. India., 13(1), 1961, $50-55$.

[15] R. G. Michael, A new rotifer Conochilus madurai from an astatic water pool in Madurai. Zool. Anz., 177, 1966, 439-441

[16] M. Rajendran, On a new species of Conochilus from Madurai, Proc. Ind. Acad. Sci.,73, 1971, 8-14.

[17] V. Sampath, A. Srinivasan and R. Ananthanarayanan, Rotifers as biological indication of water quality in Cauvery River. Proc. Symp. Environ. Biol., 1974, $441-452$.

[18] L. Kannan and C. Govindasamy, Rotifers of Portonovo (brackish water) (CASMB Portonovo Publication, 4, 1991).

[19] S. G. Patil, Rotifers (Fauna of Nilgiri Biosphere Reserve. Fauna of Conservation Area Series, 11, $2001,25-30$.

[20] R. R. Daisy, Taxonomy and resting egg morphology of freshwater rotifers, Ph.D., thesis, MS University, Tirunelveli, 2001.

[21] S. Baskaran, L. Isaiarasu and A. Thangamani, Observations on diurnal variations in physical chemical and zooplanktonic components of a pond in Sivakasi. Oikoassay., 5(2), 1998, 51-95.

[22] L. Isaiarasu and K.K. Raja, Observation on seasonal changes in the zooplankton density of pond in Sivakasi. Oikoassay., 14(1\&2), 1997, 17-21.

[23] N. Chellaiah, Studies on cladocerans and Rotifers of a Seasonal and a perennial pond of Sivakasi Taluk, Tamil Nadu, M.Sc., Dissertation, M K University, 2006.

[24] B. K. Sharma, The Indian species of the genus Brachionus (Eurotatoria: Monogononata: Brachionidae), Hydrobiologia., 104, 1983, 31-39.

[25] B. Pejler, On the global distribution of the family Brachionidae (Rotatoria). Arch. Hydrobiol. Suppl., 53, 1977, 255-306.

[26] P. Lingam, Biodiversity of freshwater zooplankton in seasonal ponds of Sriviliiputtur taluk and Sivakasi taluk, Virudhunagar district. M.Sc. dissertation M. K. University, 2007.

[27] R. Suresh Kumar, V. Annaraj Gladson and J. Thampiraj, Hydrobiological study of a perennial pond in ANJAC campus. Proc. Nat. Sem. App. Zool., 2007, 33 - 36. 